\title{
Malnutrition in a Modernising Economy: The Changing Aetiology and Epidemiology of Malnutrition in an African Kingdom, Buganda c.1940-73
}

\author{
JOHN NOTT * \\ School of History, University of Leeds, Leeds, West Yorkshire, LS2 9JT, UK
}

\begin{abstract}
The ecological fecundity of the northern shore of Lake Victoria was vital to Buganda's dominance of the interlacustrine region during the pre-colonial period. Despite this, protein-energy malnutrition was notoriously common throughout the twentieth century. This paper charts changes in nutritional illness in a relatively wealthy, food-secure area of Africa during a time of vast social, economic and medical change. In Buganda at least, it appears that both the causation and epidemiology of malnutrition moved away from the endemic societal causes described by early colonial doctors and became instead more defined by individual position within a rapidly modernising economy.
\end{abstract}

Keywords: Malnutrition, Kwashiorkor, Poverty, Buganda, Uganda

The changing incidence of hunger and famine continues to assume a central place in the history of modern Africa. However, the history of malnutrition has never received the same detailed attention. Instead, nutrition and nutritional disease are often simply addressed as an intractable part of the broader history of food security.

Although nutritional diseases and localised periods of food insecurity were certainly not unheard of in the pre-colonial period the onset of colonial rule seems to have accompanied widespread food insecurity and an increasing incidence of malnutrition - the result of population pressure, epidemic disease, the erosion of indigenous child protection measures and untenable increases in the demand for labour. ${ }^{1}$ John Iliffe describes this as a fundamental, continent-wide shift in food security away from famine and towards malnutrition and 'non-fatal scarcity' determined by social position. Michael Watts, on the other hand, suggests that famine became more common yet less severe than in

* Email address for correspondence: j.d.nott@leeds.ac.uk

I would like to thank Shane Doyle for all of his advice regarding this paper as well as the thesis upon which it is based. Thanks also to the anonymous reviewers and the editor for their comments on the previous versions of this article.

${ }^{1}$ S. Rijpma, 'Malnutrition in the History of Tropical Africa', Problèmes Africains Contemporains, 42 (1996), 4563; Jan Kuhanen, Poverty, Health and Reproduction in Early Colonial Uganda (Joensuu: University of Joensuu, Faculty of Humanities, 2005); Shane Doyle, 'Population Decline and Delayed Recovery in Bunyoro, 18601960', Journal of African History, 41 (2000), 430-53; M. Howard and A.V. Millard, Hunger and Shame: Poverty and Child Malnutrition on Mount Kilimanjaro (London: Routledge, 1997). 
the pre-colonial economy. ${ }^{2}$ In either case, the increasing visibility of nutritional disease probably helped allow for the 'discovery' of malnutrition in the 1920s. ${ }^{3}$ The subsequent development of colonial nutrition research was clouded by misdiagnoses, perceptions of cultural superiority and the pervasive paternalism which characterised tropical medicine at large. In this environment the medical and social discourse concerning nutritional illness focused the blame on inclement environments and African food culture, and away from the structural shortfalls of colonial rule. ${ }^{4}$

The emergence of Amartya Sen's 'entitlement approach' to famine causation in the 1980s provided historians of famine with a malleable tool to explain the demographic make-up of famine mortality. ${ }^{5}$ By directing attention away from conventional supply-side explanations of food crises characterised by an 'extreme concentration on the ratio of food supply to population', the entitlement approach instead provided an analysis which treats any shortfall in food availability as a symptom of demand failure influenced by differences in social capital and socio-economic status. ${ }^{6}$ Megan Vaughan's 1987 study, for example, used entitlement analyses to detail which groups starved and which did not during the 1949 famine in Nyasaland, now Malawi. In Zambia, whose history Vaughan examined with Henrietta Moore, the social relations of consumption and hunger were also actively shaped by processes of social and geographical differentiation, with women in particular suffering from increased demands for labour and a loss of economic flexibility associated with labour migration and monetisation. ${ }^{7}$ Recent work on the political economy of famine by Alex de Waal and David Keen bolsters these arguments while adding new complexity to our understanding of food insecurity, showing for example that famine is neither a natural event nor simply an episode of mass death through starvation. Instead, famines often work along social lines created or exploited by powerful local agents. ${ }^{8}$

In general, entitlement analyses such as these have focused on explaining famine mortality and, by extension, nutritional morbidity during periods of micro- and macroeconomic stress. Historians have, however, paid much less attention to changing patterns of nutritional status when considered as independent from widespread crises of subsistence. This overt concentration on food security has then largely ignored the creation of malnutrition as a non-crisis event, while also failing to put it in historical context. By contrast, this paper will focus instead on times of plenty, examining how nutritional status

\footnotetext{
2 John Iliffe, Famine in Zimbabwe, 1890-1960 (Gweru: Mambo Press, 1990), 11; Michael Watts, Silent Violence: Food, Famine and Peasantry in Northern Nigeria (Berkeley, CA: University of California Press, 1982), 272.

${ }^{3} \mathrm{M}$. Worboys, 'The discovery of colonial malnutrition between the wars', in D. Arnold (ed.), Imperial Medicine and Indigenous Societies (Manchester, 1988), 208-25.

${ }^{4}$ Worboys, op. cit. (note 3), 222-3; Cynthia Brantley, Feeding Families: African Realities and British Ideas of Nutrition and Development in Early Colonial Africa (Portsmouth, NH: Heinemann, 2002); Dianne Wylie, Starving on a Full Stomach: Hunger and the Triumph of Cultural Racism in Modern South Africa (Charlottesville, VA, and London: University Press of Virginia, 2001).

5 Amartya Sen, Poverty and Famines: An Essay on Entitlement and Deprivation (Oxford: Oxford University Press, 1981).

${ }^{6}$ Amartya Sen, 'Development: Which way now?', Economic Journal, 93 (1983), 756.

${ }^{7}$ Megan Vaughan, The Story of An African Famine: Gender and Famine in Twentieth Century Malawi (Cambridge: Cambridge University Press, 1987); Henrietta L. Moore and Megan Vaughan, Cutting down Trees: Gender, Nutrition, and Agricultural Change in the Northern Province of Zambia, 1890-1990 (London: J. Currey, 1994).

${ }^{8}$ Alex de Waal, Famine that Kills: Darfur, Sudan (Oxford: Oxford University Press, 2005); David Keen, The Benefits of Famine: A Political Economy of Famine and Relief in Southwestern Sudan, 1983-9 (Princeton, NJ: Princeton University Press, 1994).
} 
and the epidemiology of malnutrition were affected by inequality but also by social and cultural factors unrelated to socio-economic standing.

Here the East African kingdom of Buganda provides a useful case study. Buganda, a precolonial power in the African great lakes, enjoyed a remarkable degree of food security yet suffered widespread malnutrition throughout the twentieth century. Colonial doctors and officials were quick to explain that this was the result of a social and cultural predisposition to endemic malnutrition. However, massive advances in colonial medicine and education failed to erase malnutrition from Buganda's medical statistics. Any positive impacts brought by Buganda's swelling social services appear to have been quickly undermined by the increasing incidence of forms of malnutrition less closely associated with culturally prevalent diets or child-rearing practices but instead tied to new forms of poverty growing throughout the kingdom.

Few parts of Africa produced such detailed data on malnutrition, morbidity, mortality and social differentiation as Buganda, one of the most heavily researched areas on the continent throughout the post-war period. While it may be that Buganda was not fully representative of wider trends, although land shortage and underemployment were becoming ever more prevalent in the context of rapid population growth and economic under-performance, the severity of nutritional disorders in Buganda should be of broad interest given that malnutrition reduced resistance to diarrhoeal diseases, respiratory infections and other leading causes of mortality in the developing world during this period. ${ }^{9}$

\section{Nutrition, Poverty and Entitlements in the Context of Pre-colonial Buganda}

To the earliest European explorers of Buganda, a constituent part of the 'fertile crescent' of Uganda, the lack of physical want in the kingdom was immediately apparent. In the 1870s Henry Morton Stanley described Buganda as a land of 'luxurial plenty ... a land of butter and wine and fullness, milk and honey, fat meads and valleys' ${ }^{10}$ Despite this natural fecundity, protein-calorie deficiencies, known locally as 'muhinyo, muhinye or bihimbo' illnesses which would eventually come to be defined as 'kwashiorkor' - were apparently endemic by at least the beginning of the twentieth century. ${ }^{11}$ By the mid-1940s the colonial administration stated that 'the majority of children in Buganda show signs of malnutrition', with nutritional deficiencies thought to influence about twenty per cent of infant deaths. ${ }^{12}$

The frequent incidence of kwashiorkor, the regional prominence of Kampala's Makerere Medical School and Mulago Hospital, sustained investment from the UK's Medical Research Council (MRC), and close institutional relationships with Great Ormond Street Hospital and other specialist British units combined to make Buganda the global centre of

\footnotetext{
${ }^{9}$ S. Preston, 'Causes and consequences of mortality declines in less developed countries during the twentieth century', in Richard A. Easterlin (ed.), Population and Economic Change in Developing Countries (Chicago: University of Chicago Press, 1980), 289-360.

${ }^{10}$ H.M. Stanley, Through the Dark Continent (London: George Newnes, 1899), 381.

${ }^{11}$ Government of Uganda, Annual Report of the Medical and Sanitary Department, 1908 (Entebbe: Government Printer, 1909), 34; H.C. Trowell and E.M.K. Muwazi, 'A Contribution to the Study of Malnutrition in Central Africa: A Syndrome of Malignant Malnutrition', Transactions of the Royal Society of Tropical Medicine and Hygiene, 39 (1945), 232; Cicely D. Williams, 'Kwashiorkor: A Nutritional Disease of Children Associated with Maize Diet', The Lancet, 226 (1935), 1151-2.

12 Nutrition Sub-Committee, Review of Nutrition in Uganda: A Summary of Previous Work and An Appreciation of the Present Position (Entebbe: Government Printer, 1945), 3-5; J.N.P. Davies, 'Pathology of Central African natives, Mulago Hospital Post-Mortem Studies, VII: Causes of Death in African Children', East African Medical Journal, 25 (1948).
} 


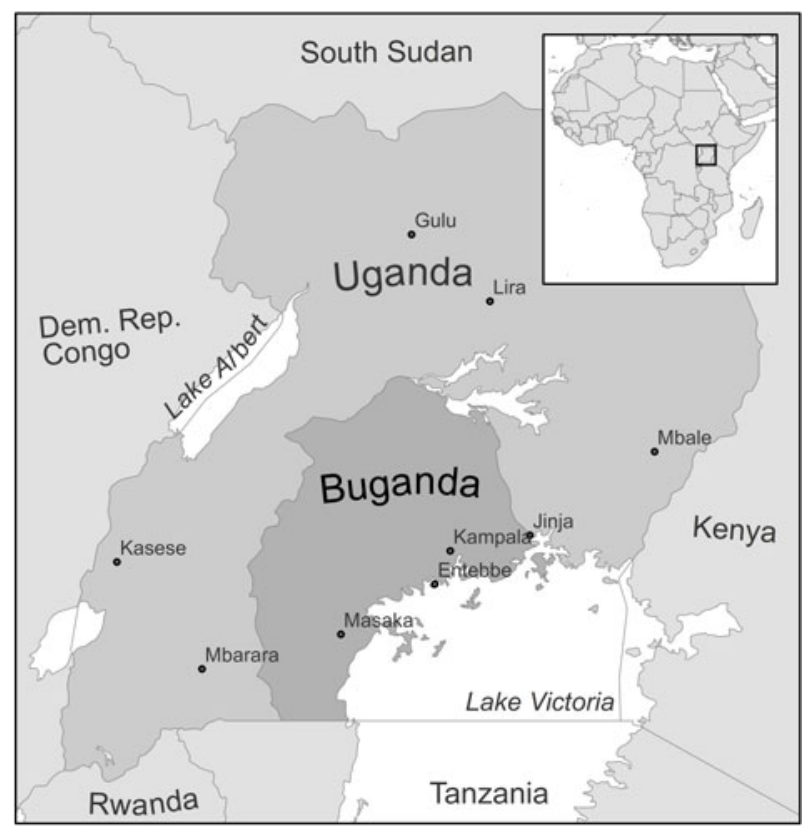

Figure 1: Buganda within Uganda and modern Africa.

nutrition research between 1940 and the political turmoil of the 1970s. The rich medical literature produced mainly by long-term resident expatriate doctors during those years was fundamental to modern physiological understandings of protein malnutrition. It also provides insight into the changing socio-economic causes behind nutritional disease in Buganda specifically.

Although malnutrition partially results from the economics of food acquisition, the severity and frequency of malnutrition in Buganda - a prosperous, food-secure part of Africa - transcended a purely economic formulation, especially one suggestive of supplyside failure. Part of this has to do with the nature of the nutritional diseases discussed in this paper. Kwashiorkor, resulting from insufficient protein; marasmus, resulting from insufficient total calories; and the combined condition, marasmic kwashiorkor, form a spectrum of deficiency defined as 'protein-energy malnutrition'. ${ }^{13}$ While these deficiencies are related, the marked differences in the epidemiology and social aetiology of the various conditions are often overlooked. McCance and Rutishauser wrote that, in Uganda, the standard perception was that 'kwashiorkor predominates in the banana and cassava areas where infants are commonly weaned at a relatively early age onto these low protein staples', areas exemplified by Buganda, while it was commonly held that 'marasmus is commoner and kwashiorkor less common in the areas of sorghum and finger millet cultivation, that is mainly in the north and east of Uganda, where at certain times poor rainfall may lead to an overall shortage of food'. ${ }^{14}$ However, as kiganda society changed

\footnotetext{
13 It should be noted that the 'classical' aetiology of kwashiorkor as a protein deficiency is not universally accepted. The biology of kwashiorkor is not a closed book and the pathophysiology of kwashiorkor is still not fully understood. With this proviso, the classical aetiology of kwashiorkor is used throughout this paper.

${ }^{14}$ R.A. McCance and I.H.E. Rutishauser, 'Childhood malnutrition', in S.A. Hall and B.W. Langlands (eds),
} 
with the twentieth century, so did the causes of malnutrition and the relative places of economy and culture in its overall aetiology. ${ }^{15}$ In Buganda specifically, Trowell and Muwazi's 1945 paper lists 200 cases of 'malignant malnutrition' affecting primarily poor labourers from Rwanda and Burundi and Baganda children under three years of age. ${ }^{16}$ Malnutrition related to poverty - in this case adult presentations of malnutrition - was, during the 1940s, seen to mainly affect marginal, immigrant labourers rather than the indigenous Baganda. This began to change in the decades that followed.

In the largely marasmic areas of Uganda, poverty was often the primary cause of malnutrition. However, as Jan Kuhanen has explained, the kiganda folk tradition suggests the nature of poverty in pre-colonial Buganda was somewhat divorced from that seen in other parts of the continent, usually only resulting from physical incapacity, sickness or old age. ${ }^{17}$ These were forms of poverty which, according to John Iliffe's definitions, broadly come under the banner of 'structural poverty', long-term poverty caused by an individual's personal or social circumstances. ${ }^{18}$ Moreover, even if some Baganda did succumb to a comparative level of poverty, their situation did not necessarily constitute destitution or, importantly, hunger since, in Buganda;

Obuwava: tebukozza

Poverty does not make one thin. ${ }^{19}$

The strength of the pre-colonial subsistence economy cannot be understated. Even a modest, poorly tended shamba (garden) could feed a family to repletion. Nor was the problem a lack of land, for if an individual wanted a shamba, they would just need to obtain permission from the chief to clear enough land (or adopt an abandoned patch) large enough to settle themselves. ${ }^{20}$ Due to the kingdom's relatively unencumbered social mobility only the incapacitated and alone would consistently fall into hunger.

Similarly, personal and familial poverty was also rarely what Iliffe defines as conjunctural - temporary poverty into which ordinarily self-sufficient people may be thrown by crisis - because of the ease with which able-bodied Baganda could modify their 'entitlement packages' or access to sufficient food, alongside the infrequency of droughts, invasions and other disasters. ${ }^{21}$ Clinical malnutrition and conjunctural crises are usually linked by the sacrifice of nutritional status, which is often the primary response to any negative shift in 'exchange entitlement', however, even this should be considered a rarity in the configuration of early colonial malnutrition.

\section{The Cultural Causes of Endemic Malnutrition}

In colonial Buganda malnutrition was usually attributed to social rather than economic causes. The mantra of the colonial state was that malnutrition is not due so much

Uganda Atlas of Disease Distribution (Nairobi: East African Publishing House, 1975), 89.

15 A note on terminology: Buganda refers to the land, Baganda to the historically indigenous people, Muganda to an individual, Luganda to the language, and Kiganda to the culture.

16 Trowell and Muwazi, op. cit. (note 11), 230.

${ }^{17}$ Kuhanen, op. cit. (note 1), 34.

18 Iliffe, The African Poor: A History (Cambridge: Cambridge University Press, 1987), 4.

${ }^{19}$ Ferdinand Walser, Luganda Proverbs (Berlin: Reimer, 1982), 316.

${ }^{20}$ M.W. Mukiibi-Katende, 'A Comparative Analysis of the Pre- and Post-Colonial Land Tenure Systems in Buganda: Which one is the Most Suitable for the Future?', The Uganda Journal, 49 (2003), 15-9.

${ }^{21}$ Iliffe, African Poor, op. cit. (note 18), 4. 
Baganda Nilotic group $\quad$ Ruanda-Urundi

$\begin{array}{lccc}\text { Number examined } & 129 & 143 & 52 \\ \text { Kwashiorkor } & 14(10.9 \%) & 0 & 6(11.5 \%) \\ \text { Mild protein-energy } & 31(24 \%) & 7(4.9 \%) & 14(26.9 \%) \\ \text { malnutrition } & & & \end{array}$

Source: Jelliffe, 'Pediatrics in Uganda', op. cit. (note 53), 59.

Table 1: Malnutrition seen in children (1-5 years) of three different ethnicities on first attendance at child welfare clinics in the vicinity of Kampala, 1959.

\begin{tabular}{|c|c|c|c|}
\hline & Baganda & Nilotic group & Ruanda-Urundi \\
\hline Number examined & 262 & 195 & 101 \\
\hline Severe marasmus & $5(1.9 \%)$ & $1(0.5 \%)$ & $2(2 \%)$ \\
\hline $\begin{array}{l}\text { Mild protein-energy } \\
\text { malnutrition }\end{array}$ & $18(6.9 \%)$ & $8(4.1 \%)$ & $11(10.9 \%)$ \\
\hline
\end{tabular}

to absolute poverty as to ignorance, conservatism and superstition'.22 While these conclusions have to be tempered by the ubiquity of the cultural racism present throughout the colonial establishment, Buganda's alluvial soils, consistent rainfall and agricultural security did ensure that before the 1950s there was little of the under-nutrition and povertyproduced malnutrition seen in other parts of the country and other parts of the continent. ${ }^{23}$ Instead, the Baganda economy and diet were based upon the perennial cultivation of the economically hyper-efficient but nutritionally lacking plantain, which could yield ten times the produce of a yam garden without the need for storage. ${ }^{24}$ For all its benefits, the pervasive staple of steamed plantain, known as matoke, provided only one tenth of the protein and a little under a quarter of the energy of the same weight of maize-based staples. ${ }^{25}$ Given the enormous quantity of matoke that was consumed, energy requirements were usually met with ease but protein intake was aligned with the much more variable intake of supplementary foodstuffs. As plantain agriculture began to combine with other culturally prevalent causative factors, kwashiorkor was seen to be endemic amongst Baganda children and at least loosely aligned with ethnicity (Tables 1 and 2).

This food environment was particularly dangerous during weaning and for recently weaned children whose first solid food was almost always too low in both protein and energy. In the absence of appropriate high-protein weaning foods many children

\footnotetext{
22 Nutrition Sub-Committee, op. cit. (note 12).

23 Wylie, op. cit. (note 4), 164.

24 C.C. Wrigley, Crops and Wealth in Uganda: A Short Agrarian History (Kampala: East African Institute of Social Research, 1959), 7-8; D.L. Schoenbrun, A Green Place, a Good Place: Agrarian Change, Gender and Social Identity in the Great Lakes Region to the 15th Century (Oxford: James Currey, 1998), 79.

${ }^{25}$ B.W. Langlands, 'Manpower and nutritional energy resources in Uganda', in R.J. Hyde and B.W. Langlands (eds), Occasional Paper No. 58: Patterns of Food Crop Production and Nutrition in Uganda (Kampala: Department of Geography, Makerere University, 1974).
} 
were fed primarily on soft, starchy staples which filled to repletion but were lacking nutritionally. ${ }^{26}$ One study from the 1970 s found that: 'When fed on their home diet, ad lib., five times daily, only five out of the ten children achieved intakes of over 418 kilojoules and 2 grams of protein per kilo of body-weight per day ... at home, children of this age are fed only once, twice or at the most three times daily and, according to the mothers, the amount of food offered is generally less than the amount that was being offered during the study. When questioned, the mothers all said that they thought we were giving too much food. ${ }^{27}$ This was a particular problem amongst the Baganda, who saw matoke as a 'super food', and one which still inhabits a central place in Baganda culture. ${ }^{28}$ This factor was compounded by the Baganda's cultural predisposition to early weaning, something undoubtedly exacerbated by the implementation of colonial taxation and increasing demands put upon female labour. ${ }^{29}$ Breastfeeding was often quickly curtailed after a mother fell pregnant with another child as, in the kiganda perception of disease, the heat from an unborn foetus may give rise to obwosi (kwashiorkor) in nursing children. These children were frequently sent away to wean, usually to an aunt or grandmother, where they regularly received less protein-rich foods and, often, less care. ${ }^{30}$ Surveys at the Mpigi Health Centre suggested that sending away children for weaning was the practice for the 'majority of parents', regardless of whether they were expecting another child. ${ }^{31}$ The sudden cessation of breastfeeding in some such cases undermined immunity, while removal from the mother often left the child emotionally disturbed, withdraw, and with a suppressed appetite. ${ }^{32}$ Cases of marasmus were similarly seen as cultural creations since the gradual displacement of breastfeeding by the use of unsterilised bottles containing cow's milk, sweet tea or excessively diluted formula provided significantly inferior nutrition and allowed the transmission of gastrointestinal infections. Welbourn found that the first manifestations of this diarrhoeal marasmus in Uganda occurred amongst the Baganda in the early 1950s due to their early utilisation of Western bottle-feeding techniques. ${ }^{33}$ The promotion of breastmilk substitutes by Western companies famously described as 'murder' and 'the most criminal form of sedition' by Cicely Williams was a particular problem in Buganda. As Uganda's most developed

\footnotetext{
26 James McDowell, 'Patterns of protein availability and utilisation in Uganda', in V.F. Amann, D.G.R. Belshaw and J.P. Stanfield (eds), Nutrition and Food in an African Economy (Kampala: Department of Rural Economy, Makerere Library, 1972), 149.

${ }^{27}$ I.H.E. Rutishauser and J.D.L. Frood, 'The Effect of a Traditional Low-Fat Diet on Energy and Protein Intake, Serum Albumin Concentration and Body-Weight in Ugandan Preschool Children', British Journal of Nutrition, 29 (1973), 267.

${ }^{28}$ H.F. Welbourn, 'Notes on Differences Between Baganda and Luo Children in Kampala', The East African Medical Journal, 32 (1955), 294.

${ }^{29}$ Rijpma, 'Malnutrition', op. cit. (note 1), 60.

${ }^{30}$ H.F. Welbourn, 'Custom and Child Health in Buganda: Methods of Child Rearing', Tropical and Geographical Medicine, 15 (1963), 126.

${ }^{31}$ D.B. Jelliffe and F.J. Bennett, 'Cultural and Anthropological Factors in Infant and Maternal Nutrition', Federation Proceedings, 20 (1961), 185-7.

${ }^{32}$ F.J. Bennett et al., 'Family health at Kasangati', in M.J. Bonnal and I. Paul-Pont (eds), Les Conditions de vie de l'enfant en milieu rural en Afrique: Colloque organisé à Dakar (Paris: Centre International de l'Enfance, 1968), 79-80; Mary D. Ainsworth, Infancy in Uganda: Infant Care and the Growth of Love (Baltimore, MD: John Hopkins Press, 1967), 137.

${ }^{33}$ F.J. Bennett and J.P. Stanfield, 'The clinical conditions and aetiology of malnutrition in Uganda', in V.F. Amann et al. (ed.), Nutrition and Food in an African Economy (Kampala: Department of Rural Economy, Makerere Library, 1972), 4; H.F. Welbourn, 'Bottle Feeding: A Problem of Modern Civilisation', Journal of Tropical Pediatrics, 3 (1958), 157-66.
} 
region, Buganda was the primary market for the trade in formula and the centre of 'commerciogenic malnutrition'. 34

Nutritional status was also seen to correlate with ethnicity for groups other than the Baganda. Many migrants in colonial Uganda were precariously placed in the rural and semi-rural economies and were amongst the first to suffer widespread malnutrition as a result of poverty. Usually without access to adequate cultivatable land and with little social capital, the agricultural labouring classes, largely made up of immigrants from Rwanda and Burundi, were notorious throughout the period for their poor nutrition and vulnerable position at the edge of the colonial economy (Tables 1 and 2). ${ }^{35}$ Their nutritional health was further exacerbated by the conversion to kiganda diets both out of necessity and as part of widespread cultural assimilation. ${ }^{36}$ By contrast, the Kenyan Luo that made up the majority of the Nilotic group enjoyed comparatively safer employment as semi-skilled workers in Kampala, and so were able to sustain their traditional dietary preferences. Welbourn found that despite medical issues which were typical for city workers at the time, such as 'an excess of diseases attributable to poor hygiene', the Luo in the 1950s ate a varied diet based around high-protein cereals and were generally free of the cultural factors causing kwashiorkor in the Baganda (Tables 1 and 2). In fact, it appears that dietary differences encouraged a marked difference in the duration of lactation: Baganda mothers weaned their children fully at twelve to fourteen months and Luo mothers at eighteen to twenty months. ${ }^{37}$ As the 1960 s approached the severity of culturally produced malnutrition declined in the face of public health programmes, general education and exposure to medical advice. According to the 1948 census, Buganda's Infant Mortality Rate (IMR) was 182 per 1000, dropping rapidly to 140 in 1959 and 98 in 1969, and child mortality and crude death rates decreased along a similar pattern. ${ }^{38}$ The stillbirth rate in 1967 for Buganda was 29.7 per thousand, a considerable improvement on the 35.8 per thousand found in $1958 .{ }^{39}$ Although both IMRs and stillbirth rates can be considerably affected by nutrition, dietary improvements can only be forwarded as one of a number of contributing factors. ${ }^{40}$ What these figures instead show is how health improved for the vast majority of the population, and that improved diagnosis, treatment and understanding of malnutrition formed part of that health care. Instead of an endemic problem wilfully ignored or ignorantly approached, malnutrition as a cultural vestige was

${ }^{34}$ C.D. Williams, Milk and Murder: Transcript of a Speech Delivered to the Singapore Rotary Club, 1939 (Penang: International Organisation of Consumers Unions, 1986), 5; D.B. Jelliffe, 'Commerciogenic Malnutrition?', Nutrition Reviews, 30 (1972), 199-205.

${ }^{35}$ Latimer Musoke, 'An Analysis of Admissions to the Paediatric Division, Mulago Hospital in 1959', Archives of Disease in Childhood, 36 (1961), 305.

${ }^{36}$ Audrey I. Richards, 'The assimilation of the immigrants', in Audrey I. Richards (ed.), Economic Development and Tribal Change (Nairobi: Oxford University Press, 1973), 161-88; Shane Doyle, 'Immigrants and Indigenes: The Lost Counties Dispute and the Evolution of Ethnic Identity in Colonial Buganda', Journal of Eastern African Studies, 3 (2009), 297-8.

37 Welbourn, op. cit. (note 28), 292-3.

${ }^{38}$ East Africa High Commission, African Population of Uganda Protectorate, 1948 (Nairobi: East African Statistical Department, 1953); East Africa High Commission, Uganda Census 1959: African Population (Nairobi: East African Statistical Department, 1961); Republic of Uganda, Report on the 1969 Population Census (Entebbe: Government Printer, 1971).

${ }^{39}$ Uganda Government, Annual Report of the Ministry of Health, 1958 (Entebbe: Government Printer) (Entebbe: Government Printer, 1959), 45; Uganda Government, Medical Services Statistical Records 1966-7 (Entebbe: Government Printer, 1967), 53.

${ }^{40}$ Sana M. Ceesay et al., 'Effects on Birth Weight and Perinatal Mortality of Maternal Dietary Supplements in Rural Gambia: 5 year Randomised Controlled Trial', British Medical Journal, 315 (1997), 786. 
neutralised through the popularity of health care, wide distribution of health education and a broad rise in literacy.

Health education programmes became 'a feature of district life' in Uganda as early as the 1930s, while between 1948 and 1969 exposure to modern health care skyrocketed, with a $546 \%$ increase in hospital usage across the country. ${ }^{41}$ Maternal access to health care and health education has been found to be particularly important in bringing about improvements in child mortality and nutrition; by $193838 \%$ of pregnant women in Uganda attended a Government or Mission centre for ante-natal care, only ten years later the proportion had increased to $71 \%{ }^{42}$ By 1967 about $90 \%$ of pregnant women in Buganda attended ante-natal clinics run by the government or by a mission and, between 1959 and 1969, the number of children born in government hospitals across Buganda almost doubled. ${ }^{43}$ All the while, the number of doctors and nurses practicing swelled as Uganda gained independence in 1962, and gender inequality in health care provision rapidly declined. ${ }^{44}$

Formal education interacted with this infrastructural growth to improve child survival throughout the period, as has been seen throughout the developing world. ${ }^{45}$ In Buganda in the early 1970 s 'between $25 \%$ and $30 \%$ of the variations in nutritional status or recovery of the children attending the outpatient clinics could be attributed to variations in knowledge and the attitudes of the mother' ${ }^{46}$ In the first years of independence, nearly 10,000 Ugandan girls were completing their primary education annually, compared to only 73 in 1937 and 500 in 1943. By 1961 education represented 24\% of Uganda's annual governmental expenditure. ${ }^{47}$ After 1940, more and more girls were going to school and earning an education with which they could imbibe printed health-related literature and diffuse its message amongst their neighbours and friends. This educational environment carried on into adulthood through government-sanctioned women's clubs such as the YWCA, the Uganda Council of Women and the Mothers' Union. By the early 1970s there were 4000 women's clubs in Uganda, each with 25-30 members. Outside speakers and trained members regularly lectured on topics of health, child care, agriculture and home economics. ${ }^{48}$ By the time of the Amin regime, women's groups held so much influence that all independent groups were banned and reorganised under the state-sponsored National Council of Women. ${ }^{49}$

Despite these advances, nutritional disorders continued to influence the kingdom's medical statistics and the prevailing discourse continued to cite cultural causes. The

${ }^{41}$ R.S.F. Hennessey, Personal Reminiscences, RH/ODRP/Afr.S.1872 Box XVIII (1985); Uganda Government, Annual Report of the Ministry of Health, 1948 (Entebbe: Government Printer, 1949); Uganda Government, Medical Services Statistical Records 1969-70 (Entebbe: Government Printer, 1970).

42 John C. Caldwell, 'Routes to Low Mortality in Developing Countries', Population and Development Review, 12 (1986), 200; Uganda Government, Annual Report of the Ministry of Health, 1948 (Entebbe: Government Printer, 1949), 7.

43 Uganda Government, Medical Services Statistical Records, 1967-8 (Entebbe: Government Printer, 1968).

${ }^{44}$ Uganda Government, Annual Report of the Ministry of Health, 1959 (Entebbe: Government Printer, 1960); Uganda Government, Medical Services Statistical Records, 1969-70 (Entebbe: Government Printer, 1970).

45 Caldwell, 'Routes to Low Mortality', op. cit. (note 42), 179; J.C. Caldwell and P.F. McDonald, 'Influence of Maternal Education on Infant and Child Mortality: Levels and Causes', Health Policy and Education, 2 (1982), 251-67.

46 Jan Hoorweg and Ian McDowell, Evaluation of Nutrition Education in Africa: Community Research in Uganda, 1971-2 (The Hague: Mouton Publishers, 1979), 94.

${ }^{47}$ Uganda Government, Annual Report of the Education Department, 1937-61 (Entebbe: Government Printer).

${ }^{48}$ Hoorweg and McDowell, op. cit. (note 46), 30-1.

49 Aili Mari Tripp, Women and Politics in Uganda (Madison, WI: University of Wisconsin Press, 2000), 15. 
1950-2

1960-2

Breast-fed for more than 14 months

Breast-fed for 12-14 months

Breast-fed for 6-12 months

Breast-fed for 1-6 months

Total number of children

Supplementary bottle feeds before

6 months
$30(13.4 \%)$

$134(60.1 \%)$

$50(22.4 \%)$

$7(3.1 \%)$

223

$14 \%$
$34(13.9 \%)$

$117(47.8 \%)$

$50(20.4 \%)$

$32(13.1 \%)$

245

$42 \%$

Source: Jelliffe, 'Pediatrics in Uganda', op. cit. (note 53), 56.

Table 3: Duration of breast-feeding among Baganda children attending child welfare clinics in 1950-2 and 1960-2.

insufficient lactation linked with the Baganda after the Second World War continued. In the mid-1950s Welbourn found that that 'few Baganda babies were entirely satisfied on the breast for more than about six months' and in the early 1970s Rutishauser suggested Baganda lactation was inadequate for a normal rate of growth after only three months. ${ }^{50}$ Even if lactation duration continued to decline for the Baganda, the rapidly increasing use of bottle feeds and supplementation (Table 3) was less firmly linked with gastrointestinal infection in the 1960s as compared to the 1950s and, where it was, it was attached to linguistic and educational isolation, and often corresponding demands on female labour.

Improvements in health education and female literacy over the course of 1960s caused a sharp decline in hygiene-related infant mortality. In the early 1960s, deaths among neonatal admissions to Mulago Hospital were due primarily to tetanus neonatorum and gastro-enteritis, diseases both firmly linked with poor hygiene. In 1963, 94\% of neonatal admissions across Uganda had diarrhoea. By the end of the decade though, mortality among newborn admissions to Mulago due to both tetanus neonatorum and diarrhoea had both declined sharply, with only $8.5 \%$ of neonatal deaths now being attributed to these two causes, suggesting that standards of hygiene had greatly improved over the course of the decade. $^{51}$

Still, malnutrition remained significant throughout this period. However, the nature of malnutrition was changing in response to advances in health care and education. In 19678, the death rate in Buganda for children coming to hospital with kwashiorkor was 0.76 while, by comparison, the corresponding rate for the rest of Uganda, excluding Buganda, was 4.86 . In the same years, Buganda, with a quarter of the national population, made up $66.1 \%$ of the outpatients and $19.5 \%$ of the inpatients treated for kwashiorkor in Uganda. ${ }^{52}$ These figures suggest that, while kwashiorkor had endured and was still widely prevalent, the severity of malnutrition in Buganda was watered down by the progress of Buganda's social services, that popular understanding of nutritional disease was forthcoming, and that community use of medicine was increasing. Instead, by 1967 it was immigrants from

\footnotetext{
50 Welbourn, op. cit. (note 28), 293; I.H.E. Rutishauser, 'Factors Affecting the Intake of Energy and Protein by Ugandan Preschool Children', Ecology of Food and Nutrition, 3 (1974), 221.

${ }^{51}$ L. Musoke, op. cit. (note 35) 305-15; B. Marasha, Causation and Prevention of Stillbirths and Post-Natal Deaths at Mulago Hospital, 1970-1 (unpublished PhD thesis: Makerere University, 1973), 47.

52 Uganda Government, Medical Services Statistical Records, 1967-8 (Entebbe: Government Printer, 1968).
} 
Rwanda and Burundi that most commonly believed a bottle was the best way to feed a child. $^{53}$

As Jennifer Tappan has demonstrated, the declining importance of cultural factors in the causation of malnutrition resulted from a rethinking by nutritional researchers in the late 1950s and early 1960s in Uganda. Recognising that a vertical campaign focusing primarily on the provision of protein supplements and ill-adapted medical propaganda had significant but ultimately limited impact, researchers such as Jelliffe and Stanfield advocated a new multi-causal approach to nutritional disorders. Nutritional interventions would now be delivered as part of a broader improvement to individual and public health. The realisation that the severity of kwashiorkor depended in part on the presence of infection fostered a more intensive focus on the provision of clean water and latrines, alongside treatment with chloraquin and penicillin. Moreover, nutritional advice was vernacularised, so that local women taught their neighbours to feed their children kitobero, a 'feast' in which a rich sauce was mixed with the carbohydrate staple. The success of the new mwanamugimu (health child) clinics in limiting the cultural aspect of malnutrition was clear by the late $1960 \mathrm{~s}^{54}$

\section{Economic Change and the Growth of Poverty-Produced Malnutrition}

Although the infant mortality rate in Buganda had declined, in 1963 nutritional disease was still evident in $20 \%$ of infant autopsies in Kampala - the same proportion as in the mid-1940s. ${ }^{55}$ However, it was now poverty which often obstructed families from taking advantage of the opportunities for improved nutrition provided by broad advances in medicine and education. In 1955, Welbourn's study of 65 kwashiorkor patients explained that none of the families appeared poor, while some seemed comparatively well-to-do. ${ }^{56}$ By 1960, however, the poverty of the family was considered an important cause in one in seven kwashiorkor cases. In 1962, an MRC report on kwashiorkor estimated that 'poverty seems to be the chief cause in about 15 per cent of the cases' ${ }^{57}$

In Kasangati, an area with a far greater degree of nutritional understanding than was typical due to the intensive work of the experimental village health centre, the causes of kwashiorkor according to a 1968 study were generally the result of familial poverty. Marginal land, inadequate childcare due to alcoholism, no cash income and maternal employment were often cited as causes. Malnutrition was associated with pressure on parental time and resources, and families with twins and children born after short birth intervals were particularly at risk. Some $65 \%$ of children with clinical kwashiorkor were being raised by a sole parent. ${ }^{58}$ If a population's familiarity with western medicine can

\footnotetext{
${ }^{53}$ Marasha, op. cit. (note 51), 47; D.B. Jelliffe, 'Pediatrics in Uganda', Clinical Pediatrics, 5 (1965), 56; F.J. Bennett and F. Alozie, 'The growth of young children in Buganda', in Bonnal and Paul-Pont, op. cit. (note 32), 91-4.

54 Jennifer Tappan, “"A Healthy Child Comes from a Healthy Mother”: Mwanamugimu and Nutritional Science in Uganda, 1935-73' (unpublished PhD thesis: Columbia University, 2010), 133, 227, 237, 252-64; D.B. Jelliffe, 'Custom and Child Health in Buganda: Introduction' Tropical and Geographical Medicine, 15 (1963), 121-3.

55 R.E. Brown, 'Paediatric Post-Mortem Survey in Uganda', Tropical and Geographical Medicine, 17 (1965), 289-300.

${ }^{56}$ H.F. Welbourn, 'Backgrounds and Follow-up of Children with Kwashiorkor', Journal of Tropical Pediatrics, 5 (1959), 91.

57 A.P. Farmer, 'Malnutrition as an Ecological Problem', East African Medical Journal, 37 (1960), 399-404; 'Infantile Malnutrition Research Unit: Progress Report, January 1962', PRO/FD/12/273.

58 Bennett et al., op. cit. (note 32), 74.
} 
be roughly estimated by their usage of maternity services then Kasangati was quite exceptional. In Kasangati, only $20.7 \%$ of mothers gave birth in their homes and away from professional help, compared to the Uganda average of $62.8 \% .{ }^{59}$ Culturally causative factors, such as the fear of obwosi, early weaning, the misuse of bottle feeding and the fostering out of young children which had dominated medical analyses of kwashiorkor among the Baganda in the 1950s were all conspicuously absent from Kasangati due to the pervasiveness of the medical information dispensed from its health centre. Instead other interrelated social and economic factors showed their presence and, in 1973, Josephine Namboze listed poverty foremost in the causes of kwashiorkor in and around Kasangati. ${ }^{60}$

Although nutritional disease was never entirely divorced from poverty, especially when considered in a global context, part of the delay in the development of a clinical association between kwashiorkor and poverty was undoubtedly due to the politically objectionable nature of economic formulations of nutritional disease at a local level. ${ }^{61}$ As Tappan explains, portraying malnutrition as an 'endemic cultural and environmental problem inherent to certain parts of the globe served to depoliticise poor nutritional health and blame the proverbial victim', shifting blame away from the colonial political economy. ${ }^{62}$ Shifts in mainstream medical opinion away from cultural stereotyping was perhaps in part to do with the decline of imperial control over medicine but, importantly, this change also correlated with the growth of poverty and hunger into the later colonial period.

As independence approached, the progress made in challenging the cultural causes of malnutrition was increasingly undermined by urbanisation, immigration and broad economic change. Cultural determinants of malnutrition were not so prevalent as in previous decades. In 1959, Musoke explained that the incidence of nutritional disease in Buganda should be defined by the geographical problems of the area in which a certain group lived, and the inequities of work, food and housing, rather than any cultural determinant. ${ }^{63}$ By the mid-1960s, whatever cultural advantages the urban Luo had previously enjoyed had been eroded by their weakened economic position in Uganda. The political disenfranchisement of foreigners in 1963 coincided with a marked decline in the amount of available work and a semi-official policy promoting jobs for ethnic Ugandans, undermining the Luo's economic domination of the capital. ${ }^{64}$ According to expenditure surveys, growing levels of poverty and under-employment meant the Luo now consumed the least protein and food overall compared to other ethnic groups, spending, on average, $84 \%$ of their income on core foodstuffs, as compared to the Baganda who only spent $71 \% .65$

\footnotetext{
59 Josephine M. Namboze, 'A Study of the Births and Deaths in the Defined Area of Kasangati Health Centre in the Year 1967', Journal of Tropical Pediatrics, 15 (1969), 101; Uganda Government, Census, 1969, op. cit. (note 38); Uganda Government, Medical Services Statistical Records 1969-70 (Entebbe: Government Printer, 1970).

${ }^{60}$ Josephine M. Namboze, 'A Rural Nutrition Rehabilitation Project at Kasangati Health Centre', Journal of Tropical Pediatrics, 19 (1973), 49.

61 Tappan, op. cit. (note 54), 53.

62 Ibid., 275.

63 Musoke, op. cit. (note 35), 305.

${ }^{64}$ David Parkin, Neighbours and Nationals in an African City Ward (Berkeley, CA: University of California Press, 1969), 45.

${ }^{65}$ Uganda Government, The Patterns of Income, Expenditure and Consumption of African Unskilled Workers in Kampala, February 1964 (Kampala: Ministry of Planning and Community Development, Statistics Branch, 1966).
} 
Mass immigration of seasonal and permanent workers from the 1930s combined with the rapidly increasing indigenous Baganda to swell the population beyond the capacity of the greatly modified rural economy. Between 1948 and 1969 the population more than doubled, with another $75 \%$ growth in the years up to 1980 , causing population densities to increase from 81 people per square mile in 1948 to 222 in $1980 .{ }^{66}$ An increasing proportion of this population was made up of wage-labourers, most of whom were ultimately looking for a parcel of land on which to grow cash-crops. However, the growth of a proto-capitalist economy which thrived on the exploitation of landless labour meant the rural population without access to land were often the poorest and most malnourished, in the region. Ethnic disparities in IMRs within Buganda go some way to prove this with, in 1959, the Baganda rate at 120 and the 'other tribe' rate at $170 .{ }^{67}$ Even if these differences cannot be explained simply in terms of nutrition they certainly suggest disparities in living conditions, poverty and access to health care. In the 1940s the death rate for temporary migrants working a wage was fourteen times higher than the Baganda death rate in Mengo district. At the Uganda Sugar Factory 'the list of causes of the 166 deaths shows that $65.6 \%$ were due to those diseases the incidence and mortality of which are recognised to be in inverse proportion to the state of nutrition' ${ }^{68}$ Increasing population densities also modified the disease environment. Measles flourished in the dense populations of the 1960s and 1970s, with the number of measles inpatients in Government Hospitals increasing from $0.6 \%$ to $4.1 \%$ of annual admissions between 1952 and $1969 .{ }^{69}$ The impact of this on kwashiorkor is unclear but measles affects malnourished children first and with most virulence, whilst also preceding clinical malnutrition in as many as $4 \%$ of cases. $^{70}$

Over the decades the make-up of the labouring class evolved as the pattern of migration changed from brief, male sojourns in Buganda to send home cash to long-term movements of whole families. ${ }^{71}$ By the early 1950s Richards found that sixty-five per cent of immigrants in Busiro were settled as tenants. ${ }^{72}$ In 1959 immigrant workers from Rwanda and its environs made up about three sevenths of Buganda's rapidly increasing population. ${ }^{73}$ Progressively though, more and more Baganda and their families were pushed into competition with migrants for wage work and tenancies. Merely finding a plot became prohibitively expensive. In the early 1950 s entry fees demanded by landlords were between Shs.100 to Shs.200, start-up capital which would take the average peasant producer several years' wage work to earn. By 1966 entry prices had increased to between

\footnotetext{
66 Uganda, Censuses, op. cit. (note 38); Uganda Government, Report on the 1980 Population Census (Kampala: Ministry of Planning and Economic Development, Statistics Division, 1982).

${ }^{67}$ Uganda, Census, 1959, op. cit. (note 38).

${ }^{68}$ R.E. Barrett, Death of Temporary Immigrant Rwanda and Allied Tribes from Belgian Congo Administered Territories, May 1942, RH/ODRP/MSS.Afr.S.1872 Box III.

${ }^{69}$ Uganda Government, Annual Report of the Ministry of Health, 1954 (Entebbe: Government Printer, 1955); Uganda Government, Medical Services Statistical Records 1969-70 (Entebbe: Government Printer, 1971); John Iliffe, East African Doctors (Cambridge: Cambridge University Press), 132.

${ }^{70}$ E.M.E. Poskitt, 'Effect of Measles on Plasma-Albumin Levels in Ugandan Village Children', The Lancet, 298 (1971), 68-70; P. Bhaskaram, 'Measles and Malnutrition', Indian Journal of Medical Research, 102 (1995), 195-9.

${ }^{71}$ C.C. Wrigley, 'The changing economic structure of Buganda', in L.A. Fallers (ed.), The King's Men: Leadership and Status in Buganda on the Eve of Independence (Oxford: Oxford University Press, 1964), 53; Uganda Government, Census, 1959.

72 Audrey I. Richards, 'Methods of settlement in Buganda', in Audrey I. Richards (ed.), Economic Development and Tribal Change (Nairobi: Oxford University Press, 1973), 132.

${ }^{73}$ Uganda, Census, 1959, op. cit. (note 38).
} 
Shs.400 and Shs.600. ${ }^{74}$ Richards' 1950s depiction of a Buganda in which 'literally nothing except a hoe' was needed to start up as a cotton producer was, by 1970, a distant memory. ${ }^{75}$

In economies so heavily based upon agriculture the acquisition of workable land is usually central to the cause of and escape from poverty and malnutrition. ${ }^{76}$ The 1900 Agreement undid the flexibility of prior systems of land tenure, with more than three quarters of Buganda's agriculturally productive land donated to the private ownership of less than one per cent of the population. ${ }^{77}$ The mailo form of land tenure led to the sedentarisation of a previously mobile population and the gradual exhaustion of soil fertility. Even the acquisition of a tenant plot was not a sure route to economic security as landlords progressively divided land into smaller and smaller parcels in order to extort the maximum amount of rent and maximum entry payments from their tenants. As early as the 1920 s the average plot size was three acres and decreasing. ${ }^{78}$ Crop yields per acre steadily decreased through the utilisation of marginal and infertile land and fallow periods shortened, while the monoculture applied in cash-cropping caused the land to degenerate and dietary variation to be reduced. Lucy Mair in the 1930s found that that highly nutritious but labour-intensive food crops millet and simsim (sesame) were being displaced by cotton and coffee. ${ }^{79}$ The insular nature of pre-colonial agriculture - in which banana leaves, skins and stems were used as mulch and human and animal waste used as manure - changed with the sale of cash-crops and the depletion of the area's soil capital. ${ }^{80}$ As early as 1936 'it was stated [in Buganda] that the shortage of land was serious and that over-cultivation was taking place leading to soil deterioration' ${ }^{81}$ In the following years, erosion and declining yields were major problems impinging on agricultural returns. ${ }^{82}$

In response to the post-war boom, the acreage under cash-crops increased rapidly in Buganda with the area under coffee and cotton expanding by seventy-three per cent between 1944 and 1965. As a result of both this and the rapid increase in population, food crop acreages per capita shrank from 0.67 in 1948 to 0.57 in 1965. In the years 19447 Buganda's favourable ecology meant that the average acre under cotton in Buganda yielded $156 \mathrm{lbs}$ more per year than the Uganda-wide average. However, as soil fertility declined, the average gap between cotton yields in Buganda and Uganda dropped to only 40 lbs in 1963-5, with Buganda's mean cotton yields shrinking by $31 \%$ per cent between these years. ${ }^{83}$ These issues were compounded into the 1950 s by global declines in cash

\footnotetext{
74 A. Mafeje and A.I. Richards, 'The commercial farmer and his labour supply', in Audrey I. Richards et al. (ed.), Subsistence to Commercial Farming in Present-Day Buganda (Cambridge: Cambridge University Press, 1973), 190.

75 Richards, 'Methods of settlement', op. cit. (note 72), 139-40.

76 John Sender and Sheila Smith, Poverty, Class, and Gender in Rural Africa: A Tanzanian Case Study (London: Routledge, 1990), 31-7, 43-5, 50.

${ }^{77}$ For land tenure in Buganda see Henry Woolliscroft West, Land Policy in Buganda (London: Cambridge University Press, 1972); A.B. Mukwaya, Land Tenure in Buganda: Present Day Tendencies (Nairobi: East African Institute of Social Research, 1953); L.P. Mair, 'Baganda Land Tenure', Africa: Journal of the International African Institute, 6 (1933).

${ }^{78}$ Kuhanen, op. cit. (note 1), 343.

79 L.P. Mair, An African People in the Twentieth Century (London: George Routledge and Sons, 1934), 111.

${ }^{80}$ C.C. Wrigley, 'Bananas in Buganda', Azania, 24 (1989), 64-70.

${ }^{81}$ G. Reakes-Williams and A. Dunbar, 'Survey of Bukeka Mutals Situated in the Gombolola Mutuba II in the County of Bulemezi', (unpublished thesis: African Studies Centre, University of Cambridge, 1964), 3.

${ }^{82}$ Kuhanen, op. cit. (note 1), 342-4; David Anderson, 'Depression, Dust Bowl, Demography, and Drought: The Colonial State and Soil Conservation in East Africa during the 1930s', African Affairs, 83 (1984), 321-43.

${ }^{83}$ Uganda, Censuses, op. cit. (note 38); Uganda Government, Annual Report of the Department of Agriculture, 1944-65 (Entebbe: Government Printer).
} 
crop prices. Over only five years cotton prices fell by about forty per cent and coffee prices crashed to less than half the wartime price. ${ }^{84}$ As the era of independence began tenant farmers were increasingly worse off; they had less land, produced a lower weight of saleable crops and made less money for their efforts.

In the 1950s, Wrigley contested that the old Kiganda adage, that it was possible for one woman in Buganda to feed ten men, still held true. ${ }^{85}$ However, by the early 1970s, over-reliance on the export economy meant, in terms of daily per capita levels of food availability, that the Buganda population consumed the lowest total food by weight, the fewest total calories and the least total protein of Uganda's four provinces, leaving the balance between requirements and availability 'at best precarious' ${ }^{86}$ Food crops as a percentage of cultivated land in Buganda slipped from $68 \%$ to $61 \%$ between 1944 and 1965, with yields simultaneously declining through encroaching pests and poor husbandry. ${ }^{87}$ Although the mid-1960s plantain acreage per family stayed about the same as the 1938 figure, 1.9 acres, the acreage per resident fell from 0.61 to 0.19 , while the acreage of other food crops fell from 2.03 to 0.75 per family and from 0.68 to 0.19 per resident. ${ }^{88}$ With drops in per-capita food production, the rural population were increasingly left to rely on a poorly developed chain of rural markets, where produce was heavily inflated by the cost of transport and by seasonality which could see pre- and post-harvest price fluctuations of over $120 \% .{ }^{89}$

With nearly double the number of livestock per capita in 1959 as compared with 1948, alongside imports of slaughter cattle from Teso and other pastoral parts of Uganda, access to animal protein in Buganda did greatly improve. ${ }^{90}$ However, much of this trade was limited by the paucity of markets. In 1968, while per capita consumption of milk averaged half a pint per person per day in Kampala, the population of Masaka, a rural community in southern Buganda, only consumed one sixtieth of a pint per person per day. ${ }^{91}$ The same was evident in terms of meat consumption, with Kampala enjoying twice the national average in 1967, although not all groups enjoyed equal access to the potential benefits of city life..$^{92}$ Over the course of a month in Masaka in 1968 it was found that two-thirds of the population consumed no meat, $61 \%$ no fish and $89 \%$ no milk. ${ }^{93}$

${ }^{84}$ R.M.A. van Zwanenberg and Anne King, An Economic History of Kenya and Uganda 1800-1970 (London: Macmillan, 1975), 190-2.

85 Wrigley, 'Changing Economic Structure', op. cit. (note 71), 22.

${ }^{86}$ McDowell, op. cit. (note 25), 136; J.H. Cleave, 'Food requirements and availability in Uganda: a national food balance sheet', in Amann et al., op. cit. (note 33), 121-2.

${ }^{87}$ Uganda, Agriculture Reports, op. cit. (note 83).

88 Malcolm Hall and D.G.R. Belshaw, Agricultural systems and nutrition problems in Uganda, in Amann et al., op. cit. (note 33), 176.

89 Oloya and Poleman, 'Urban food consumption patterns in Uganda', in V.F. Amann et al., op. cit. (note 33), 95-108.

${ }^{90}$ Uganda Government, Veterinary Department Annual Report, 1948 (Entebbe: Government Printer); Uganda Government, Annual Report of the Department of Veterinary Sciences and Animal Industry, 1959 (Entebbe: Government Printer)

${ }^{91}$ Uganda Government, Report of the Committee on Marketing of Livestock, Meats, Fish and Their Produce in Uganda 1969 (Entebbe: Government Printer, 1970); Uganda Government, Rural Food Consumption Survey 1968, Ankole, Busoga, Masaka and West Nile (Entebbe: Statistics Division, Ministry of Planning and Economic Development, 1970).

92 Uganda Government, Report of Annual Agricultural Statistics July 1967-December 1968 (Entebbe: Government Printer, 1969).

93 Uganda Government, Rural Food Consumption Survey, 1968, op. cit. (note 91), 11. 


\section{Malnutrition and the Modernisation of Poverty}

Throughout the second half of the twentieth century the mass of Baganda cultivators were caught in a divergent economy. To stay in the self- or semi-self-sufficient system of their forebears would cut them off from the cash economy and the attractions of the expanding commodities market, potentially restrict their ability to send their children to school and, by way of the relative nature of poverty, make them poor in comparison to their neighbours. ${ }^{94}$ However, a more or less wholesale switch to cash-cropping reduced the average tenants' ability to provide for themselves and their dependents from their own household, leading to an over-reliance on the diminishing capacity of their neighbours and Buganda's import economy for their food. All the while the kingdom's economic self-determination was subsumed by the demands of the export-economy, transforming kiganda occupational structures into what Mamdani described as the 'lowest common denominator, that of unskilled labour'. ${ }^{95}$

These new challenges were framed within the lopsided capitalist expansion which defined Uganda's economic progression into independence. Between 1945 and 1960 $£ 118.8$ million was taken in taxes from peasant producers, about $32 \%$ of their potential income. ${ }^{96}$ In 1952, the Baganda peasantry obtained only $45 \%$ of the actual value of their cotton and $43 \%$ of the value of their coffee. ${ }^{97}$ Even Wrigley, a notable proponent of Uganda's economic trajectory, acknowledged that 'for more than a decade the growers, qua growers, were consistent losers, and losers on a very substantial scale'. ${ }^{98}$ Governmental subsidisation of 'progressive' farmers was largely reserved for the already successful and, even after independence, Prime Minister Milton Obote's posturing attacks on the 'clique of selfish men' and his 'Move to the Left' in the late 1960s did little to actually redress imbalanced land relations. ${ }^{99}$

Increasingly difficult rural conditions also paired with post-war industrialisation to give rise to rapid urbanisation and the creation of an urban poor increasingly disconnected from the social ties and modes of production previously prerequisite for economic and food security. Between 1959 and 1980 the total urban population of Uganda increased by $248 \%$, while the population of the Kampala conurbation grew by as much as $8.7 \%$ per year to nearly half a million people by $1980 .{ }^{100}$ Well-established city markets and increasing wages did, however, improve access to food, standards of health and general quality of life for most of the urban populace. By 1964, unskilled Kampala labourers were spending a lower percentage of their average income on food than in the fifteen years previously, yet, in comparison to 1952 , received on average $2.65 \mathrm{lbs}$ more meat per month, $1.42 \mathrm{lbs}$ more groundnuts and $106.89 \mathrm{lbs}$ more matoke. ${ }^{101}$

\footnotetext{
${ }^{94}$ Richard W. Thompson and Roy E. Roper, 'Relative Deprivation in Buganda', Ethos, 4 (1976), 155-87.

95 Mahmood Mamdani, Politics and Class Formation in Uganda (London: Monthly Review Press, 1976), 35.

96 Van Zwanenberg and King, op. cit. (note 84), 131, 222.

${ }^{97}$ East Africa High Commission, Background to the Budget (Nairobi: East African Statistical Department, 1955).

98 Wrigley, Crops and Wealth, op. cit. (note 24), 70.

99 A. Mafeje, ISS Occasional Paper 32: Agrarian Revolution and the Land Question in Buganda (The Hague: ISS, 1973), 15-16; Apolo Milton Obote, The Common Man's Charter (Entebbe: Government Printer, 1970), Article 28, Article 35.

${ }^{100}$ Uganda, Censuses, op. cit. (notes 38 \& 66).

101 East Africa High Commission, The Pattern of Income, Expenditure and Consumption of African Unskilled Labourers in Kampala, September 1952 (Nairobi: East African Statistical Department, 1953); Uganda Government, The Patterns of Income, Expenditure and Consumption of African Unskilled Workers in Kampala, February 1964 (Kampala: Ministry of Planning and Community Development, Statistics Branch, 1966).
} 
The nutritional status of urban Buganda was then only really in question for those who were unemployed, unusually ill paid or burdened with large families. However, these were subsections of the urban population which expanded steadily over time and increasing average urban food consumption concealed sharply worsening inequality. ${ }^{102}$ As urban migrants escaped increasingly difficult agricultural lives they divorced themselves from rural systems of kinship, food supply and employment and, by the late 1960s, were potentially more at risk of malnutrition, through any temporary or permanent failure in their personal 'exchange entitlement' - in this case a shortfall in cash-earning - than their rural counterparts. ${ }^{103}$ In 1955 unemployment was not considered a problem in Kampala, it was deemed that 'anyone who really wanted work had no difficulty in finding it quickly'. ${ }^{104}$ Within only three years though, the Department of Labour reported that 'there was a surplus of unskilled labour, semi-skilled workers, domestic, clerical and other non-manual workers in the main towns'. ${ }^{105}$ On a micro-economic level, unemployment created sudden, personal economic crises and, undoubtedly, had some effect on the diets of those least prepared or able to adapt to such a situation. Throughout the 1960s, infantile malnutrition was seen twice as often in dispensaries in the more heavily urbanised Mengo district (which contained Kampala and Entebbe) than in the rest of Buganda. ${ }^{106}$

The modernisation of kinship ties undermined traditional coping mechanisms yet further. By 1955, the strength of familial bonds was 'still generally assumed, but rather on a reciprocal basis which precludes [the] long-term parasitism' which had previously advanced the children of less fortunate kin and supported the structural poor in Buganda. ${ }^{107}$ As unemployment became a problem, more young men and women were relying on the help of their friends or family for survival. ${ }^{108}$ However, with the reduced ability or inclination of the established townspeople to prop up the growing un- and underemployed population, many fell into destitution or crime. In 1968, 61\% of men arrested for property offences in Kampala were unemployed and over one third of offenders either did not see or did not have any family in Kampala as compared to only $4 \%$ of non-offenders. ${ }^{109}$ Although in 1965-6 only two per cent of Kampala's unemployed were sleeping rough, these two per cent represent a significant increase from perhaps ten years earlier when proximity to rural modes of production rendered such manifestations of destitution almost unimaginable. ${ }^{110}$ This 'kinlessness' filtered down through Baganda society. In 1911 John Roscoe explained that 'there were no orphans, because all the father's brothers were fathers to a child and the heir to a deceased person immediately adopted and became responsible

\footnotetext{
102 Iliffe, African Poor, op. cit. (note 18), 164-92.

103 Bennett and Stanfield, op. cit. (note 33), 4.

${ }^{104}$ Uganda Government, Labour Department Annual Report, 1955 (Entebbe: Government Printer, 1956), 7.

105 Uganda Government, Labour Department Annual Report, 1957 (Entebbe: Government Printer, 1958), 11; Uganda Government, Labour Department Annual Report, 1957 (Entebbe: Government Printer, 1961), 6.

106 Uganda Government, Medical Services Statistical Records 1965-70 (Entebbe: Government Printer).

107 Aidan Southall, 'Kinship, friendship, and the network of relations in Kisenyi, Kampala', in Aidan Southall (ed.), Social Change in Modern Africa (Oxford: Oxford University Press, 1961), 220; F.J. Bennett and A. Mugalula-Mukiibi, 'An Analysis of People Living Alone in a Rural Community in East Africa', Social Science and Medicine, 1 (1967), 103.

108 Caroline Hutton, Reluctant Farmers? A Study of Unemployment and Planned Rural Development in Uganda (Nairobi: East African Publishing House, 1973), 39-40.

${ }^{109}$ Marshall B. Clinard and Daniel J. Abbott, Crime in Developing Countries: A Comparative Perspective (New York: Wiley, 1973), 97, 124.

${ }^{110}$ Hutton, op. cit. (note 108), 56.
} 
for the latter'. ${ }^{111}$ By 1959, the rise in orphaned and abandoned children caused one Save the Children employee to doubt the continuation of such conventions. ${ }^{112}$

Independent women were especially at risk in this environment. In 1955, twenty-three per cent of Kampala's households were headed by women, a figure Southall took to represent 'a total and permanent escape from rural and tribal society' and its support structures. ${ }^{113}$ Women generally worked in the informal sector, eking out a living from brewing and selling beer and hawking food. Households headed by a woman were often the poorest in Kampala and, as observed elsewhere in Africa, the 'closest to total destitution'. ${ }^{114}$ Even in modern Kampala, the state of the informal sector is such that 'renting a single-room house, maintaining a family and paying school fees for the children are major problems for single women'. ${ }^{115}$ Temporary 'town marriages', in which a man would exchange food or money for rent in exchange for domestic and conjugal duties, were common, one Baganda man even suggested that if an unmarried woman in the city were to lose her temporary husband she would 'risk starvation'. ${ }^{116}$ Without any real paternal duty of care for the children conceived during these unions poor mothers had little choice but to accept another mouth to feed or seek out an illegal abortion, a choice which, in 1970, was 'definitely on the increase'. ${ }^{117}$

The cultural causes of nutritional disease were gradually displaced by a rapidly modernised social welfare regime, with those ethnically defined causes of malnutrition replaced by causes attributed to modernising social conventions and changing economic realities. Parental abandonment was increasingly cited as the primary psychological, clinical and economic cause of malnutrition across Uganda. Marasmic children in Eastern Uganda were 'always' the result of mothers that had 'run away'. ${ }^{118}$ In the 1960 s, $14 \%$ of the children treated for moderate-to-severe kwashiorkor in Kampala were displaced through the traditional fear of obwosi while $37 \%$ of children were from a 'broken home', a striking illustration of the greater significance of new social stresses over long-established cultural norms. By 1969 as many as one in fourteen women between the ages of fifteen and thirty were divorced in Buganda, as compared to one in twenty-one across the rest of the country. ${ }^{119}$ All the while, the growing demand for female labour and corresponding restraints on maternal energy were increasingly cited as causes of infant malnutrition. ${ }^{120}$

As the socio-economic structure of Buganda changed, so did the social epidemiology of malnutrition. With a broader group of people under threat from poverty, inadequate diet and nutritional disease became symptoms of economic hardship. By the 1950s

\footnotetext{
111 John Roscoe, The Baganda: An Account of Their Native Customs and Beliefs (London: Macmillan, 1911), 12.

112 Christine Partington, Report of SCF Organiser on her Activities for the Period March 23rd-June 11th 1959, For the Executive Committee of the Uganda Children's Welfare Society, RH/ODRP/MSS.Afr.S.1872 Box XXVIII.

113 Southall, op. cit. (note 107), 224.

114 A.W. Southall and P.C.W. Gutkind, Townsmen in the Making: Kampala and its Suburbs (Kampala: East African Institute of Social Research, 1957), 51-63, 136-40; Elizabeth Mandeville, 'Poverty, Work and the Financing of Single Women in Kampala', Africa, 49 (1977), 47-9; Iliffe, African Poor, op. cit. (note 18), 238.

115 Nakanyije B. Musisi, 'Baganda women's night market activities', in Andrea Cornwall (ed.), Readings in Gender in Africa (Oxford: James Currey, 2005), 134.

116 Iliffe, African Poor, op. cit. (note 18), 183; Southall and Gutkind, op. cit. (note 114), 77.

117 C. Lwanga, 'Abortion in Mulago Hospital, Kampala', East African Medical Journal, 54 (1977), 147-8.

118 Shem Y.L. Tamusange, 'Up-Country Paediatrics: Mbale, Uganda', The Makerere Medical Journal, 7 (1964), 28.

119 Uganda, Census, 1969, op. cit. (note 38).

${ }^{120}$ Bennett and Stanfield, op. cit. (note 33), 4.
} 
the economic fragility previously reserved for migrants had begun to affect the poor indigenous Baganda, with observers reporting an emerging class of Baganda cotters seeking wage employment for cash income. ${ }^{121}$ A decade later the anthropologists Archie Mafeje and Audrey Richards 'came across Baganda peasants who did not have any land at all and were doing odd jobs such as pruning, desuckering, coffee picking or brewing beer'. ${ }^{122}$ This, as Latimer Musoke, of Mulago Hospital, explained, had a commensurate effect on malnutrition as well as access to medical care:

'The life of the mothers of most of our patients is very arduous. She had the responsibility of growing food for the family, assisting the husband in cultivating fields of cash-crops, providing water and firewood for the family and looking after her own four to eight children ... It is with these problems that the mother had to forsake her home and other children to bring her sick infant to hospital. ${ }^{, 23}$

Conjunctural poverty, occasional under-nutrition and poverty-produced malnutrition were then increasingly common for a broader band of people than ever before. As rural land shortages increased, the ability to significantly modify entitlement packages was restricted and exaggerated by the simultaneous growth of a lopsided capitalist economy. Structural poverty was increasingly the result of economic isolation and social immobility, rather than the social isolation of physical incapacity seen in previous decades. The makeup of Buganda's structural poor broadened over the space of about fifty years from the dissociated, disabled and disenfranchised of the recent past to include the migrant victims of an early, exploitative form of small-scale capitalism and finally to include new, expanding groups of vulnerable Baganda - single mothers, those with large, young families and those without access to sufficient cultivatable land. As Iliffe has suggested for the continent at large, the causes of poverty and vulnerability transformed from problems associated with a shortage of labour to those arising from a shortage of land. ${ }^{124}$ While this was largely true in Buganda, decreasing soil productivity also heightened the demands on labour over time and, in this newly monetised, intensely unequal society, vulnerability arose from a wider range of circumstances. By 1970, the Baganda economy was built upon a new seam of structural poverty into which a considerable number of the population could fall at any time of conjunctural crisis. As early as 1962, the MRC had realised that 'changes in the family's economic position, brought about by losses through theft, or the failure of a crop, although causing no more than a temporary lowering of living standards, may become a major disaster for a young child'. ${ }^{125}$ As these familial crises increased in frequency into the 1960 s, the incidence of malnutrition as a reaction to economic stress rose in response.

\section{Conclusion}

The onset of colonial rule irreversibly changed the nature of food security and malnutrition across most of sub-Saharan Africa. For many Africans, the relationship between land, labour, food and family changed forever as a response to the capitalist revolution. In Buganda, as in much of Africa, the changing incidence of malnutrition was closely bound to the partial integration of the often incompatible colonial export economy with pre-

121 Wrigley, Crops and Wealth, op. cit. (note 24), 79.

122 Mafeje and Richards, op. cit. (note 74), 190.

123 Musoke, op. cit. (note 35), 305.

124 Iliffe, African Poor, op. cit. (note 18), 4-6.

125 'Infantile Malnutrition Research Unit: Progress Report, January 1962', PRO/FD/12/273. 
existing, indigenous forms of production. Meanwhile, the socio-cultural devices which had evolved to protect children from some degree of nutrition-related disease were stripped away by myriad social and economic factors related to colonial governance and domestic change.

The cultural environment which remained in Buganda caused the growth of a fairly endemic level of malnutrition largely rooted in the social upheavals caused by colonial rule. However, unable to adapt quickly to colonial capitalism, the more immediate causes were the long-standing peculiarities of Baganda society and the particularities of the local food environment. Unaware or unwilling to discuss the more distant roots of this pervasive pattern of nutritional illness, colonial doctors were prone to ascribe a great deal of importance to the social and cultural causes of malnutrition. Long-standing social characteristics such as the plantain-heavy diet, the fostering of children who were being weaned and the fear of obwosi were granted prime position in the social aetiology of endemic forms of malnutrition. These well-established causes were usually placed alongside more modern social problems. Birth-spacing shortened throughout the colonial period and was often cited as a primary cause of nutritional illness, as was the growing use of supplementary bottle feeds. Meanwhile, the fostering of children only expanded in response to increasing maternal employment. Processes of food insecurity, entitlement or poverty were, however, rarely thought to be related.

Although these conclusions have to be tempered by a critical appreciation of imperial medicine, the kingdom's remarkable ecology did mean that failures of entitlement were relatively insignificant in the make-up of pre-colonial and early colonial manifestations of malnutrition. Throughout this period, the productive capacity of the plantain economy happily satisfied basic food requirements for the vast majority. The richness of the local economy mitigated the threat of short-term hunger, or conjunctural crisis, while softening the blow to the individual or the family when such crises did occur. Chronic destitution or structural poverty was only the concern of a particularly vulnerable few, those without the physical or social capacity to provide for themselves or their dependents. Total-calorie deficiencies were rare, yet kwashiorkor was apparently endemic and unrelated to socioeconomic status, at least amongst the indigenous Baganda.

As kinship-based, communalistic modes of social security were displaced by the process of capitalist development, colonial social services grew into the space which was left behind. Nutrition formed an absolutely central part of this new state welfare. Nutrition researchers flooded Uganda's medical community from the 1930s onwards and, with MRC support, the country's social service were at the global forefront of nutritional medicine, providing pioneering education and rehabilitation into the 1970s. In response to the scientific onslaught of the first half of the twentieth century, preventable mortality and morbidity declined, literacy improved and malnutrition as a result of ignorance or cultural susceptibility appears to have dropped in tandem.

Although advances in health care and education granted a greater knowledge of nutrition and scientific medicine, they were not able to effectively address malnutrition as a problem tied to recent fundamental changes in the country's economy. In response to the agricultural commercialisation of the early 1900s, land reform began to diminish rural productivity and, by the 1960s, had excluded many from those pre-existing forms of food security which had been so central to the success of pre-colonial Buganda. All the while, the wealth of Kampala stoked urbanisation and a population explosion which heightened competition within the kingdom's already strained internal food economy. Both of these 
changes stretched and undermined the system of extended familial responsibility which had previously prevented malnutrition in times of personal crisis. Where malnutrition had been explained as an inability to provide children with food of a sufficient quality, in this environment it also came to be understood as a problem of quantity and a failure of basal subsistence. Throughout the twentieth century nutritional status was progressively linked with a more individual capacity to earn. Those processes which had previously afforded children protection from nutritional illness were undermined as the value of an individual's time and labour became more sharply realised in the average domestic economy. Nursing mothers had to find the time necessary for extended periods of protective breastfeeding. The parents of weaned children had to be able to buy or grow sufficient nutritious foodstuffs for their young children. Each family had to pay for clean water, or find or buy the fuel needed to sanitise it. Important determinants of nutritional status such as these had to be factored into stretched household budgets and could often be neglected in response to the diversified demands of a modern cash economy.

Rapid and relatively widespread improvements in the country's public services meant that the demography of those affected by nutritional disorders changed. Rather than a universalistic problem specific to Buganda's cultural and dietary environment, malnutrition became bound up with poverty and social isolation. Initially concerns only for impoverished migrants from outside of the kingdom, these were problems that broadened in demographic scope over the course of the colonial period. By the mid-1960s, malnutrition was rarely a cultural creation, a vestige of pre-colonial diet, agriculture and kiganda perceptions of disease. Malnutrition instead resulted from a lack of entitlement defined by individual position within a rapidly changing economy. Of course, entitlement was shaped by social connections while employment and land tenure were equally influenced by social factors. However, the value of traditional social capital only waned over the course of the colonial period. Increasingly, entitlement was dictated by an economic position influenced but not specifically defined by ethnicity, language or gender.

Malnutrition was latterly tied to the growth of a divergent class structure and the emergence of new forms of poverty. Colonial rule contributed to the development of a growing underclass, a structural poor furthest removed from the revolution in public services and at the mercy of the new economy. Growing dependency upon either insubstantial modern wage employment or the stifled traditional subsistence economy meant that hunger and structural poverty were built into this economic environment. Widespread movement away from the means of production likewise increased the frequency and severity of conjunctural crises and the malnutrition which could now accompany any temporary decline in income. Although the causes of poverty and povertyproduced malnutrition may have changed it was, as in the nineteenth century, those isolated and existing on the margins that were most at risk. Throughout the twentieth century, however, adherence to colonial economic structures expanded those margins, bringing food insecurity and nutritional disease to new groups and broader swathes of the population. 